C 209

\title{
スプリッタ付きネーザルＣＰＡＰ素子の特性
}

細井 健司 ${ }^{\circ}$ (埼玉大学), 川橋 正昭 (埼玉大学)

松本 崇 (埼玉大学)、平原 裕行 (埼玉大学)

\section{Performance Characteristics of a Nasal CPAP Device}

\author{
Kenji HOSOI, Masaaki KAWAHASHI, Sou MATSUMOTO and Hiroyuki HIRAHARA
}

\begin{abstract}
Artificial respiration techniques for patients with respiratory disorder are important as a basic life support treatments for the patients. The nasal CPAP (Continuous Positive Airway Pressure) is a typical clinical treatment for infants keeping self respiration. Some devices for the nasal CPAP have been used in clinical procedure. However, in order to reduce the load for patients in the treatments, the downsizing and improvement of fitting of the devices are required. A new type device of nasal CPAP has been developed by the authors, but its performance in MAP (Mean Airway Pressure) variation did not meet the condition for clinical use. In this report, the performance of a nasal CPAP device improved has been investigated and it has been clarified that the performance was meet to clinical use.
\end{abstract}

Keywords: Nasal CPAP, Artificial Respiration, PIV, Visualization

\section{1. 緒 論}

呼吸機能不全の新生児に対する呼吸管理医療では，さ まざまな人口呼吸法が適用されている。自呼吸が維持さ れている患者に対しては，肺末端組織の虚脱防止や肺の 機能的残気量を增加させて低酸素症を改善するために， 気道内を陽压に維持寸る方法がとられる。このとき，新 生児が主として鼻呼吸を行うことから，鼻孔装着型の素 子を用いた気道内陽压維持法として，ネーザル CPAP(Continuous Positive Airway Pressure)が適用さ れる。このネーザル CPAP の作動条件としては，患者の 吸気時㧍よび呼気時に気道内平均圧である MAP(Mean Airway Pressure)の変動が，なるべく小さくなるように することが求められる。このような基本的要件を満たす いくつかのネーザル CPAP のための素子が，すでに臨床 灾用されている。しかし，医療現場では，これらの素子 を装着する際の，新生児への過大負荷が問題となり，小 型化と装着性の改善が求められている。

著者らは、ネーザル CPAP 素子の小型化と装着性の改 善と同時に, MAP 变動を臨床応用に可能な範团に抑え ることを目的として，供給気流が鼻孔に詨向しない横型
ネーザル CPAP 素子の開発を行ってきた。しかし，MAP 変動值において，当初の目標には至らなかった，そこで， 特に呼気時の圧力上昇の低減を目指して, 給気ノズル出 曰に噴流分配用の楔形スプリッ夕を形成するとともに， スプリッタ背後と仕切り板の間に陌間を設けた改良型の ネーザル CPAP 素子の 2 次元モデルを作成し，その特性 を調バた。その結果，MAP 変動値が，現用の CPAP 素 子とほぼ同様の值となることが明らかにされ，臨床忍用 可能な素子開発への知見が得られた。

\section{2. 実験装置}

本実験で用いられたネーザル CPAP素子モデルの概略 図がFig.1に示されている。 $5 \mathrm{~mm} \times 1 \mathrm{~mm}$ のスリット状 断面を有する給気ノズル，広がり角 25 度のディフュー ザ部，MAP 発生のためのよどみ部，大気放出部からな る.また，ノズル出口㣪流に幅 $5 \mathrm{~mm}$, 長さ $4 \mathrm{~mm}$ 、先 端角度 15 度の楔状スプリッタが形成されている。スプ リッタ先端位置は、ノズル出口から下流側に $1 \mathrm{~mm}$ ，噴 流中心軸に対して上方に $0.5 \mathrm{~mm}$ シフトされている。ス プリッタ背後の仕切板との隙間 Lは， 0 $5 \mathrm{~mm} の$ 範囲で 調整される。 


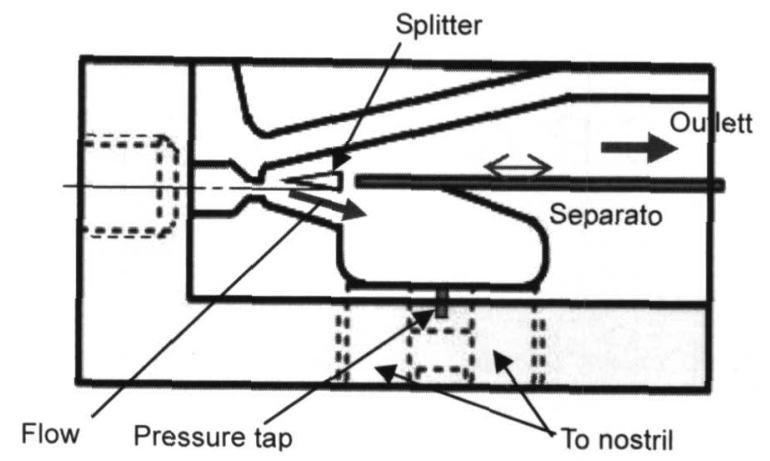

Fig. 1 Schematic view of nasal-CPAP device.

CPAP 素子は、アクリル製であり，流路前面はフロー トガラスを用いた観測空である。本実験では出口部を大 気開放としている。

Fig.2 に実験装置を示寸。供給空気は, 面積流量計、 チャンバーを経て、CPAP 素子モデルに流入する。呼吸 は, 減速歯車付モータにより駆動されるクランク機構に 接続されたシリンジによる機械式人工肺により模擬され る。なお，呼吸の各位相における可視化および PIV 計測 は, モータに取り付けられたタイミング板（1 周期 8 分 割) と光学系との組み合わせにより発生させた同期信号 により制御される。素子内よどみ部の圧力は鼻孔装着プ ロングの中央部で、圧力測定孔（ $\phi 0.2 ）$ に接続された増 幅器付微差圧計で測定され、ノズル入口圧力は、超小型 デジタル圧力センサで測定される。それぞれの圧力変動 波形とタイミング信号は、データロガーにより記録され る。定性的可視化用光源にはアルゴンイオンレーザ（出 力 $4 \mathrm{~W})$ を, PIV 計測にはダブルパルス YAGを用いて、 高速度デジタルハイスピードカメラ（XS-5）により時系

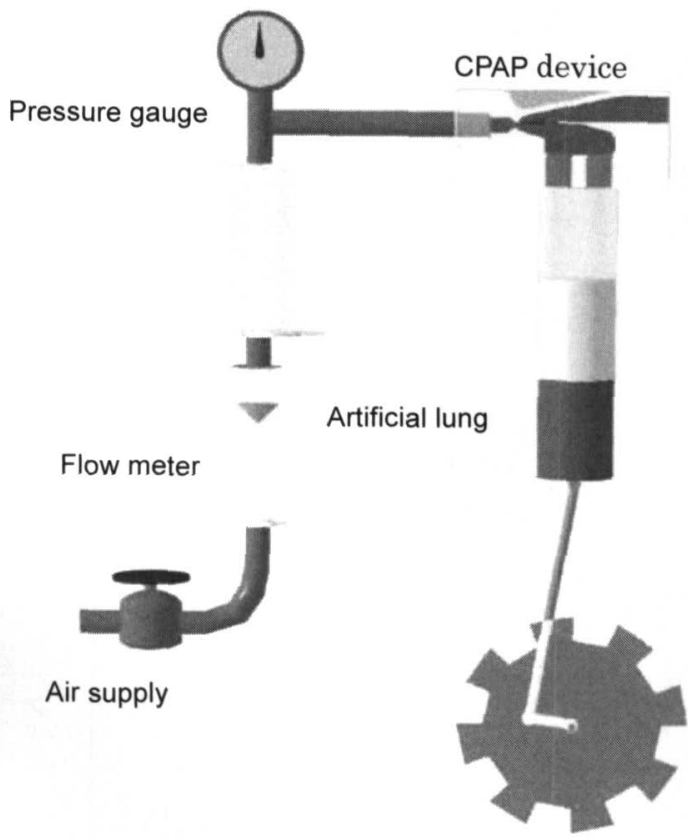

Fig. 2 Experimental setup.
列画像を記録した。トレーサには、線香の煙が用いられ た。実験条件としては，供給流量を 6〜9l/min、呼吸回 数と換気量を、それぞれ 50 回 $/ \mathrm{min}$ と $10 \mathrm{ml}$ /回とした。

\section{3. 実験結果}

\section{1 圧力測定}

最初に、定常状態におけるスプリッタと仕切り板との 隙間によるよどみ部圧力(MAPに相当)の変化を, 供給流 量を変化させて調べた。このとき供給流量は，6〜 91/min とした，その結果を Fig. 3 に示す。

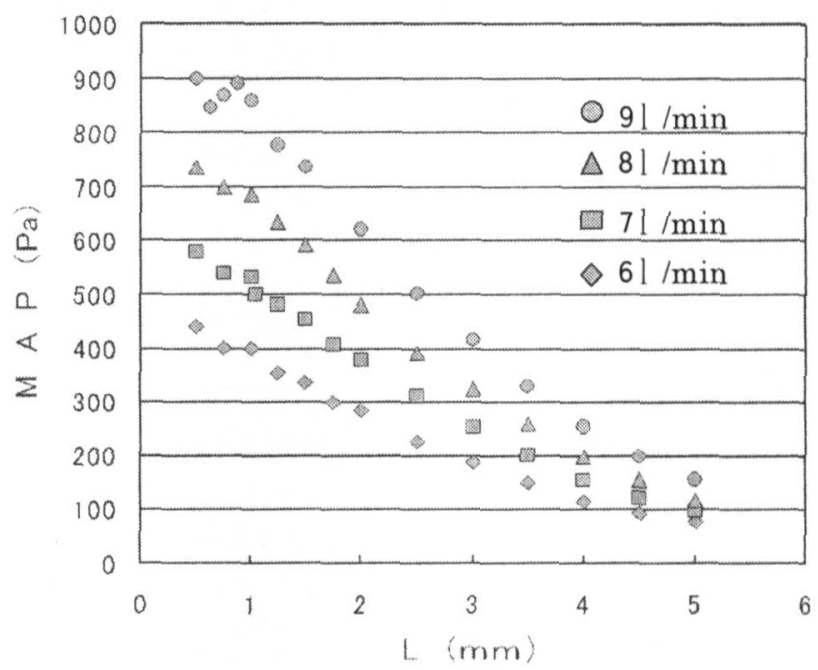

Fig. 3 Change of MAP with distance between splitter and separator for different flow rates.

図より各流量での MAPは、スプリッタと仕切板との間 隔を増すとよどみ部から出口部への流出面積が増加し、 単調に減少している。供給流量が増加寸ると、MAP は 増加する。新生児に対寸るネーザル CPAP 条件は，通常 鼻腔内圧が 300〜 500P a で行われることから、本実験で 用いた素子を用いる場合，図よりスプリッタと仕切板と の隙間は、1〜 3mm 程度とする必要がある。

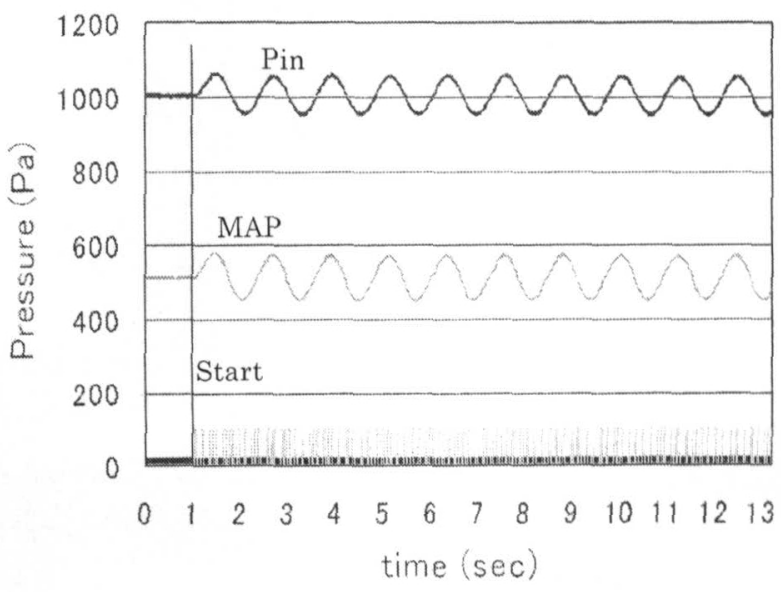

Fig. 4 Changes of MAP and inlet pressure in respiration mode. 


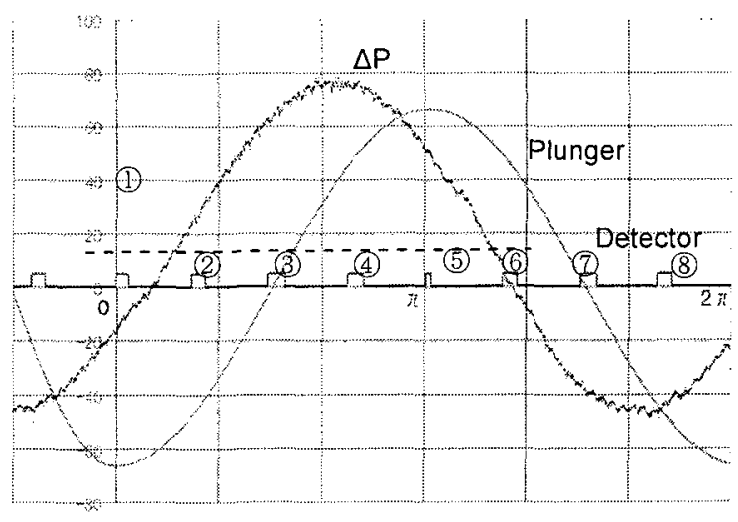

Fig. 5 Phase relation between pressure change in device and plunger displacement.

そこで供給流量が $71 / \mathrm{min}$ の場合、スプリッタと仕 切板間の距離を調整して、CPAP 内の MAP を約 $500 \mathrm{~Pa}$ に維持し、人工肺を作動させたときのノズル入口圧力変 動波形と MAP 波形，および同期信号波形を Fig.4 に示 す。図中スタート点住、人工肺のプランジャ死点と する。 MAPを $500 \mathrm{~Pa}$ にした維持した場合、ノズル入口 压力は約 $1 \mathrm{KPa}$ である。ノズル入口圧力は，CPAP素子 内圧力とほぼ同位相で変化し，圧力振幅もほぼ同じ 120Pa であることがわかる。この CPAP 変動圧力は、現 在実用化されている CPAP素子による変動圧力と同じオ 一ダーである。

次に呼吸 1 周期間の $\mathrm{CPAP}$ 素子内変動圧力 $\Delta \mathrm{P}$ とプラ ンジャ変位、同期信号の関係を Fig. 5 に示寸。プランジ ヤ下死点(1)から，(5)の上死点までが呼気周期である。上 死点(5)から吸気が開始され、下死点(1)で終了する。素子 内の圧力は, 鼻孔プロング通過流量変動に応じて変動す ることから，プランジャ変位に対して $\pi / 2$ だけ位相が進 んでいることが予想される。しかし，図より，その位相 差は約 60 度であることが分かる。このことは、プラン ジャによる排除体積速度が最大になる位相に対して，素 子内の圧力が帠大となる位相が約 30 度遅れることを示 している.さらに，供給流量と幾何学的条件を一定にし て, 模擬呼吸動作状態にすると，素子内の平均圧力が， 定常状態で得られるMAP 值に対して約 $16 \mathrm{~Pa}$ (約 $3 \%$ 増）上昇方ることが分かる。これらの動作特性は，呼吸 時の素子内流れ状態とどの上うな関係になっているかを 定量的に明らかにすることが，呼吸時の MAP 変動振幅 を減少させるための重要な要素となる。

Fig. 6 は、供給流量一定としたときの，呼吸動作時の スプリッタと仕切板間距離 Lの変化に対寸る $\mathrm{CPAP}$ 素子 内压力変動 $\Delta \mathrm{P}$ の関係を示す。このとき呼吸動作時での Lの変化に対するMAP 値は、Fig.3に示した定常時に比 較して僅かに増加する。 $\Delta \mathrm{P}$ は、L が約 $0.75 \mathrm{~mm}$ 以下で は大きな值を示し、0.75〜2 $\mathrm{mm}$ でほぼ一定となり、2 $\mathrm{mm}$ 以上では滅少している。この傾向は、流量が増えて

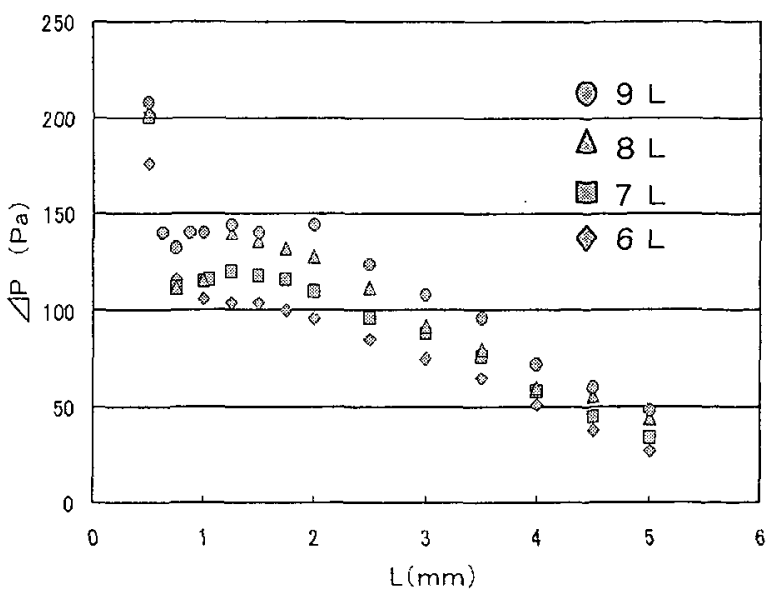

Fig.6 $\Delta \mathrm{P}$ level change with distance between splitter and edge.

も同樣であるが、流量増加に伴って $\Delta \mathrm{P}$ は単調に増加す る。

前述のように呼吸作動時には MAP と $\Delta \mathrm{P}$ はLによっ て変化するが、ネーザル CPAP 素子の特性として最も重 要な点は、吸気および呼気時に、如何にMAP の変動を 少なくできるかが重要である。そこで、本萻子を用いた 場合に、必要な MAP を発生させながら、呼吸動作時に どの程度の MAP 変動 $(\Delta \mathrm{P})$ に押さえられるかについて 明らかにするため、MAPに対する $\Delta \mathrm{P}$ の分布図を求め、 Fig. 7 に示す。この図に扔いて、各流量における MAP と $\Delta \mathrm{P}$ の関係は Lによって異なり、MAP の最大值は $\mathrm{L}$ が 0.5mmのときに生じ、Lの增加とともに MAP と $\Delta \mathrm{P}$ が減少している。Fig. 7 より，MAPに対する $\Delta \mathrm{P}$ の分布 は、流量によらずほぼ同一線上に分布している。その延 長上には、仕切り板が無いときの值がプロットされてお り、仕切り板によってMAP が生じていることがわかる。 また、MAPが $500 \mathrm{~Pa}$ のとき $\Delta \mathrm{P} か ゙ ~ 120 \mathrm{~Pa}$ 程度となって おり、この結果は現用の CPAP 素子における值とほぼ同

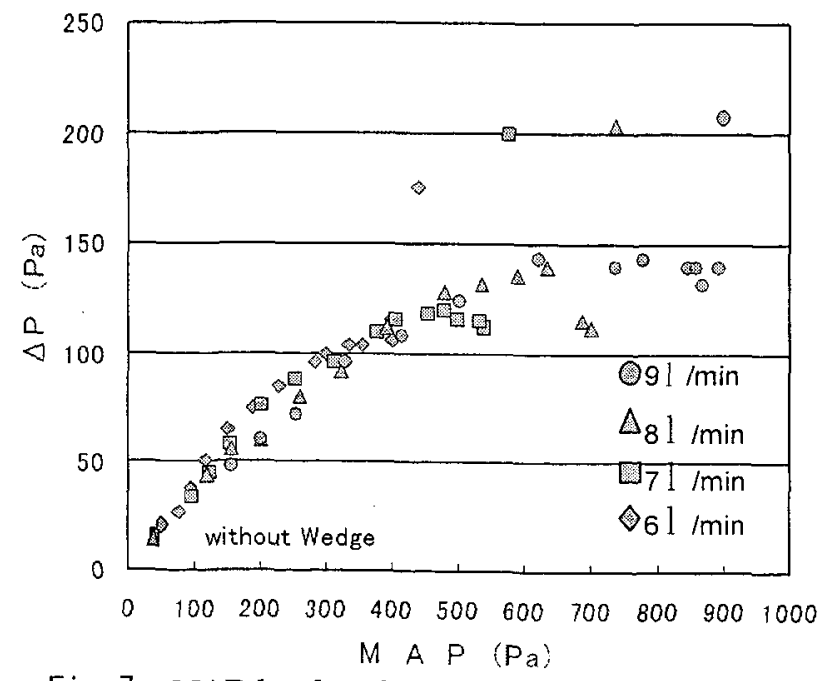

Fig. 7 MAP-level and pressure fluctuation $\Delta P$. 
じオーダーとなっている。

\section{2 可視化}

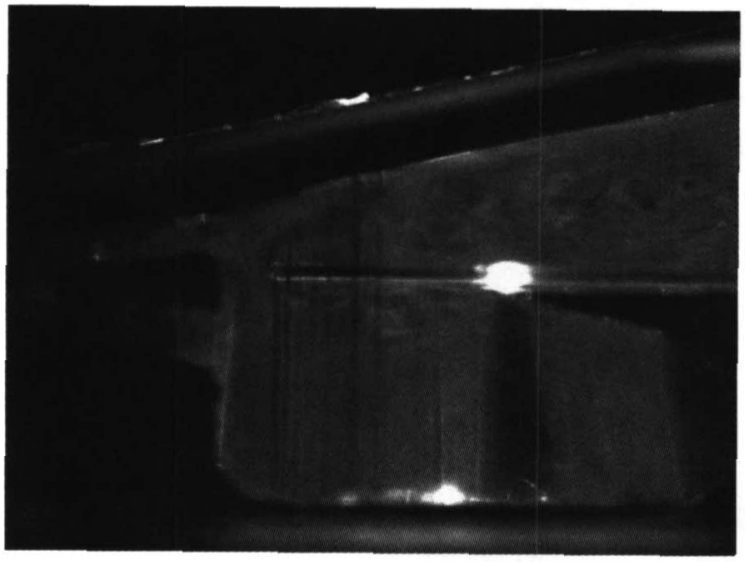

Fig. 8 Visualization of flow nasal-CPAP device.

上述の結果を、素子内の流動状態に関連付けて考察す るため、以下に流れの可視化および PIVによる定量的流 速場計測結果を示す。

はじめに人工肺を作動させていない定常状態で、レー ザライトシート法により CPAP 内の流れを定性的に可視 化した結果をFig. 8 に示す。実験条件は、供給流量を $71 / \mathrm{min} 、 \mathrm{MAP}$ を $500 \mathrm{~Pa}$ 、スプリッタと仕切板との隙間 を約 $1 \mathrm{~mm}$ とした。使用したレンズは $\mathrm{f}: 105 \mathrm{~mm}$ であり、 露光時間は $100 \mu$ 秒である。Fig.8 より、ノズルからの 流れは、ディフーザ下面とスプリッタ下面との間を通り、 キャビティ部に入り、流れの一部は、スプリッタと仕切 板との隙間部を通過し、直接出口部に向かっていること が分かる。また，一部はよどみ室での循環流を形成して いる。

\section{3 流速計測}

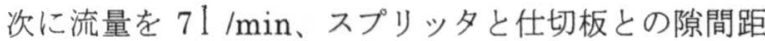
離を $1 \mathrm{~mm}$ 一定とし、呼吸を模擬したときの呼気・吸気 時について、PIVで得られた流速分布計測結果をそれぞ れ Fig. 9(a)および (b)に示す。照明時間間隔は、 $1 \mu$ 秒 である。それぞれの図に示されている基準ベクトルの大 きさは、 $30 \mathrm{~m} / \mathrm{s}$ に相当する。Fig. 9 (a) は呼気時を示して おり、スプリッタ下部からキャビティ内に流入した流れ の一部が、スプリッタと仕切板との隙間部で上方に曲げ られ、よどみ室内を循環した流れと合流して出口部に向 かっていることが分かる。その流れの流速は、ノズル出 口部平均流速 $23 \mathrm{~m} / \mathrm{s}$ と同程度である。Fig. 9 (b) は吸気時 を示しており、ノズルからの流れは、仕切板先端から下 面に沿ってよどみ室に向かっている。その流れは、壁面 に沿って曲げられ、右側プロング入りロ直前では $12 \mathrm{~m} / \mathrm{s}$ 程度に減速されおり，一部がプロングから鼻腔部に流入 している。

これらの流動状態が、MAP を維持しながら新生児の 患者の呼吸負荷を軽減することになる。

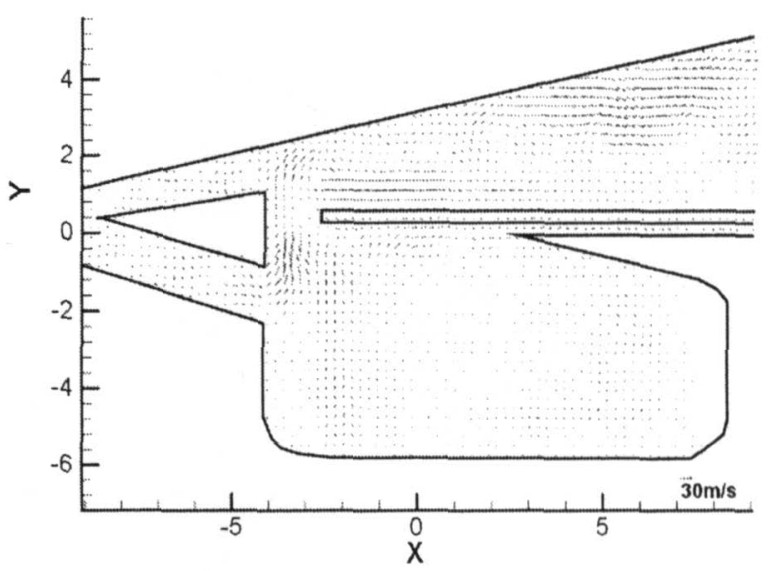

(a) expiratory phase.

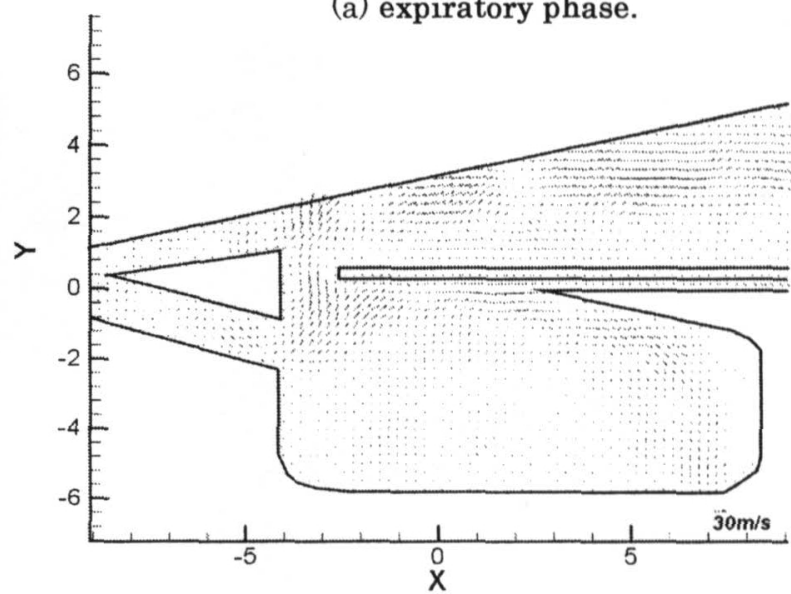

(b) inspiratory phase.

Fig. 9 Velocity distribution of nasal-CPAP device.

\section{4、まとめ}

ノズルからの流出噴流が直接鼻孔に対抗しないタイプ の横型ネーザル CPAP 素子について, 特に呼気時の抵抗 低減を目的として改良した素子の特性を実験的に調べ、 臨床応用に可能な MAP 変動を実現できることを明らか にした。また、このような特性と素子内流れとの関連に ついて調べた結果、呼気時と吸気時の素子内流れの切り 替わり状態が明らかにされ、さらに実用化に向けて検討 すべき知見が得られた。

\section{参 考 文 献}

1）細井、他 3 「ナーザル CPAP 素子内流れの可視化」、 可視化情報、Vol23 Suppl.No.1(2003),p425-426 